\title{
Antigen induced suppression in peripheral blood and lamina propria mononuclear cells in inflammatory bowel disease
}

\author{
H R Dalton, P Hoang, D P Jewell
}

\begin{abstract}
Using an autologous system, suppressor cell function to a range of mycobacterial antigens and Kunin antigen of peripheral blood mononuclear cells and lamina propria lymphocytes has been investigated in normal subjects and patients with inflammatory bowel disease. In the peripheral blood there was reduced antigen induced suppression in patients with Crohn's disease in remission to Mycobacterium paratuberculosis, purified protein derivative (PPD), $M$ fortuitum, and Kunin antigens $(\mathbf{p}<0.05)$. In patients with ulcerative colitis in remission there was reduced antigen induced suppression in the peripheral blood to Kunin antigen $(\mathrm{p}<0.001), M$ avium ( $<<0.01), M$ nonchromogenecin, and $M$ fortuitum $(p<0.05)$. The phenomenon of antigen induced suppression was largely CD8 dependent, as depleting CD8+ cells reduced the effect and the concentration of soluble CD8 in the culture supernatant was directly related to the suppressor index $(r=0.25, p<0.05)$. These results are likely to be a true reflection of the cell mediated response to antigen as patients with a positive Mantoux skin test have a significantly higher suppressor index to PPD than Mantoux negative subjects $(\mathbf{p}<0.05)$. These findings may have significance in the aetiopathogenesis of inflammatory bowel disease. However, a similar effect could not be shown in the lamina propria lymphocytes of patients having colectomy for active disease.
\end{abstract}

The aetiology of inflammatory bowel disease is unknown. There is increased immune activation in both Crohn's disease and ulcerative colitis, particularly at mucosal level. One hypothesis to explain these immunological changes is that there is reduced suppressor cell function in inflammatory bowel disease.

After Hodgson's original description of reduced suppressor cell function in the peripheral blood mononuclear cells (PBMC) of patients with inflammatory bowel disease ${ }^{1}$ several others followed. Most of these PBMC studies found similar results to Hodgson's. ${ }^{2-7}$ However, some workers found no difference between normal and control subjects. ${ }^{8-10}$ Several studies of suppressor cell function of lamina propria lymphocytes have been reported ${ }^{11-15}$ with discordant results.

The reasons for these discrepancies could be several. Differing methods were used in each study, the earlier studies largely using allogeneic systems. Furthermore, in most of these studies lectin was used to induce the suppressor cell population. This makes it even more difficult to understand the pathophysiological importance of this in vitro work as, in vivo, antigen(s) will be responsible for suppressor cell activation. There has been only one reported study of antigen specific suppressor cell function in inflammatory bowel disease in which Ebert et al described increased suppressor cell function in inflammatory bowel disease to antigen derived from Mycobacterium paratuberculosis. ${ }^{16}$

There has been renewed interest in the pathophysiological role of mycobacteria in Crohn's disease. ${ }^{17}$ This has centred on $M$ paratuberculosis, which causes a granulomatous ileocolitis in ruminants. Much effort has been invested in culturing tissue specimens from patients with inflammatory bowel disease for mycobacterial organisms, and to date $M$ paratuberculosis has been isolated from nine patients with Crohn's disease ${ }^{18}$ However, the importance of this is not clear as atypical mycobacteria have also been isolated from normal subjects and patients with ulcerative colitis. ${ }^{19}$ Little is known about the effect of mycobacteria on cellular mechanisms in inflammatory bowel disease, but if mycobacteria are important in the pathophysiology, it would seem logical to expect differences in cellular responses to mycobacteria in patients with these diseases compared with normal subjects.

A bacterial antigen which has created interest in ulcerative colitis is the common enterobacterial antigen of Kunin. Kunin antigen shares epitopes with a colonic mucopolysaccharide antigen to which haemagglutinating antibodies are found in patients with this disorder. In addition, antibodies to germ free rat colonic epithelium detected in the serum of patients with ulcerative colitis cross react with Kunin antigen. ${ }^{20}$ Using an immune complex model of colitis in rabbits, Mee et $/ a l$ showed that a chronic colitis developed in animals who had been immunised with Kunin antigen. ${ }^{21}$

The aim of this study was to investigate cellular responses to mycobacterial and Kunin antigens in inflammatory bowel disease by studying antigen induced suppressor cell function in isolated PBMC and lamina propria lymphocytes of patients with Crohn's disease, ulcerative colitis, and normal control subjects.

\section{Patients and methods}

SUBJECTS

Ten patients with Crohn's disease (median age $=46$ years, range $32-63$ ), nine patients with ulcerative colitis (median age 49 years, range 26-61), and 10 normal volunteeers (median age

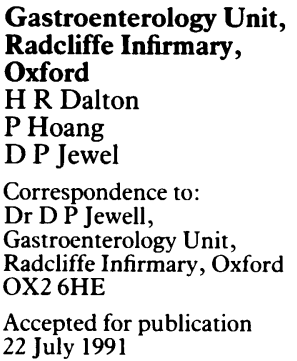


31 years, range 28-49) were studied. The patients with Crohn's disease had their diagnoses confirmed histologically or radiologically. All were in remission at the time of the study: none were taking corticosteroid medication but three were taking sulphasalazine; five patients had ileocolonic disease and five had ileal disease only.

The patients with ulcerative colitis had their diagnoses confirmed by standard clinical, radiological and histological criteria. All nine patients had disease limited to the left side; six were taking sulphasalazine, two olsalazine, and one mesalazine. None were taking steroids or azathioprine, and all were clinically in remission at the time of the study. The normal volunteers were laboratory staff. None had any important chronic or acute illness and none were taking any regular medication.

\section{PBMC ISOLATION}

PBMC were obtained by Ficoll-isopaque density centrifugation. The cells were then resuspended to a concentration of $1 \times 10^{6} \mathrm{cells} / \mathrm{ml}$ in culture medium consisting of RPMI 1640 with HEPES buffer $(25 \mathrm{mmol})$ and $2 \mathrm{mmol} / \mathrm{l}$ glutamine (GIBCO, Paisley Scotland) plus penicillin (100 $\mathrm{U} / \mathrm{ml})$, gentamicin $(50 \mu \mathrm{g} / \mathrm{ml})$, and $10 \%$ fetal calf serum.

\section{INDUCTION OF SUPPRESSOR CELLS}

Three $\times 10^{6}$ PBMC were incubated in $25 \mathrm{~cm}$ culture flasks for seven days at $37^{\circ} \mathrm{C}$ in $5 \% \mathrm{CO}_{2}$, with one of a series of antigens. The antigens used were Johnin purified protein derivative (PPD) (extract from $M$ paratuberculosis, Ministry of Agriculture, Central Veterinary Laboratory, Weybridge, Surrey, UK), tuberculin PPD (Evans Medical Ltd, Horsham, England, UK), Kunin antigen (kind gift of Professor W Bartnik, Warsaw, Poland), $M$ avium 1479, $M$ kansasii 8 , $M$ nonchromogenicin $\mathrm{R} 812 \mathrm{R}, M$ vaccin $\mathrm{R} 859 \mathrm{R}$, $M$ fortuitum II 1387 (all kindly donated by $\mathrm{Dr}$ J L Standford, London, UK). The latter five antigens were suspensions of ultrasonicated mycobacteria made up in $M / 15$ borate buffered saline. The Kunin antigen used was a lyophylised extract of ultrasonicated enterobacteriacae. All these antigens were used at a dose of $10 \mu \mathrm{g} /$ $\mathrm{ml}$, except the Kunin antigen, which was used at a dose of $50 \mu \mathrm{g} / \mathrm{ml}$. These concentrations were considered optimal from dose-response experiments performed before the main study.

For each subject, one aliquot of isolated PBMC was incubated for seven days without the addition of antigen.

\section{COCULTURE EXPERIMENTS}

After seven days the induced cells were ultracentrifuged at $500 \mathrm{~g}$ for 10 minutes. The supernatants were removed and stored at $-20^{\circ} \mathrm{C}$ for later use and the cells washed three times in culture medium. The viability of the cells was assessed by the Trypan blue exclusion method and they were then irradiated with 2500 rads and resuspended to a concentration of $1 \times 10^{6}$ cells $/ \mathrm{ml}$. Fresh autologous PBMC responder cells were isolated at the same time using Ficoll- isopaque density centrifugation. A coculture experiment was then performed, using the following cell mixtures:

(1) $5 \times 10^{4}$ PBMC induced with antigen and subsequently irradiated were mixed with $5 \times 10^{4}$ fresh autologous PBMC plus $2.5 \mu \mathrm{g} / \mathrm{ml}$ concanavalin A (suboptimal dose).

(2) $5 \times 10^{4}$ PBMC cultured without antigen and subsequently irradiated were mixed with $5 \times 10^{4}$ fresh autologous PBMC plus $2.5 \mu \mathrm{g} / \mathrm{ml}$ concanavalin A.

(3) $5 \times 10^{4}$ PBMC induced with antigen and irradiated were mixed $5 \times 10^{4}$ fresh autologous PBMC alone.

(4) $5 \times 10^{4} \mathrm{PBMC}$ cultured without antigen and irradiated were mixed with $5 \times 10^{4}$ fresh autologous PBMC alone.

The coculture was performed at $37^{\circ} \mathrm{C}$ in $5 \%$ $\mathrm{CO}_{2}$ in a $96 \mu$-well plate (Cell-Cult, Hounslow, UK) for 64 hours. The total reaction volume in each well was made up to $150 \mu \mathrm{l}$ with culture medium and all experiments were performed in triplicate. Sixteen hours before the end of the coculture, each well was pulsed with $1 \mu \mathrm{Ci}$ of [Methyl- $\left.{ }^{3} \mathrm{H}\right]$ thymidine (Amersham Laboratories, Amersham, UK). The cells were then harvested using an automated Titertek cell Harvester (Skatron, Lier, Norway) on filter paper discs. These were then suspended and centrifuged in $10 \mathrm{ml}$ of scintillation fluid (OptiPhase 'Safe', LKB) and counted on a scintillation counter.

\section{SUPPRESSOR INDEX}

The suppressor index (SI) for each antigen was calculated using the following formula:

$$
1-\frac{(1)-(3)}{(2)=(4)} \times 100 \%
$$

Positive SIs indicated active suppression, and negative SIs indicated lack of suppression or help.

\section{CELL DEPLETION STUDIES}

Several experiments were performed using a CD8 + cell depleted population. The cell depletion was performed using CD8+Dynabeads (Dynabeads M-450, Dynal, Oslo, Norway). The coculture experiments and SI calculation were performed using the same method as for the undepleted cell populations. Adequate depletion of these cell populations was confirmed by immunofluorescent staining with the appropriate monoclonal antibody followed by analysis by flow cytometry (FACScan, Becton Dickinson).

\section{SOLUBLE CD8 STUDIES}

Supernatants taken after seven days of culture with each antigen were assayed for soluble CD8 using an enzyme immunoassay test kit (cell free $\mathrm{T}_{8}$ test kit, $\mathrm{T}$ Cell Sciences, Cambridge, MA, USA).

\section{SKIN TESTS}

Skin tests were performed using tuberculin PPD 


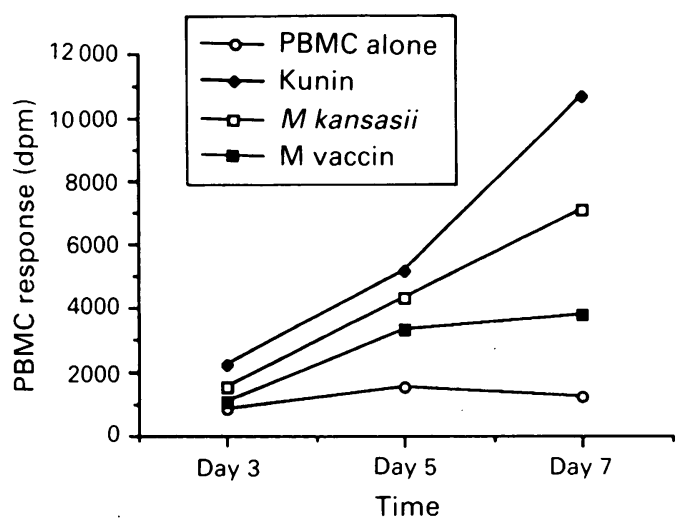

Figure 1: Typical proliferative response of peripheral blood mononuclear cells $(P B M C)(\mathrm{dpm})$ to optimal dose of Kunin, Mycobacterium and $M$ vaccin at days 3, 5, and 7.

and Johnin antigens. $0 \cdot 1 \mathrm{ml}$ of each antigen at a concentration of $20 \mu \mathrm{g} / \mathrm{ml}$ was injected intradermally into the velor aspect of each forearm. The test was read after 72 hours and was regarded as positive if greater than $5 \mathrm{~mm}$ of induration was present.

\section{LAMINA PROPRIA LYMPHOCYTES}

Antigen induced suppressor cell function was also assessed in lamina propria cells. Twenty two subjects were studied in total, using colonic resection specimens.

The control group consisted of macroscopically normal colonic mucosa from nine subjects (carcinoma $\mathrm{n}=4$, adenoma $\mathrm{n}=2$, idiopathic constipation $n=2$, and diverticular disease $n=1$ ). Seven patients with ulcerative colitis were studied (severe acute ulcerative colitis $n=6$, dysplasia $n=1$ ) and six patients with Crohn's disease (ileocolonic $\mathrm{n}=2$ ileocaecal stricture $n=4)$. Six of seven patients with ulcerative colitis and five of six patients with Crohn's disease were receiving corticosteroids at the time of the resection.

The lamina propria lymphocytes were isolated as previously decribed ${ }^{22}$ using a modification of the method of Bull and Bookman. ${ }^{23}$ The median yield of cells from control subjects was $4.0 \times 10^{6} / \mathrm{g}$ tissue (range 2.5-9.2 $\times 10^{6}$ cells $/ g$ ), from patients with Crohn's disease $11.4 \times 10^{6}$ cells/g (range $\left.5 \cdot 0-15 \cdot 0 \times 10^{6}\right)$, and from ulcerative colitis $10 \cdot 1 \times 10^{6}$ cells $/ g$ (range $4 \cdot 0-13 \cdot 3 \times 10^{6}$ ). The lamina propria lymphocytes $\left(5 \times 10^{4}\right)$ were then incubated with each antigen for seven days, washed, irradiated, and cocultured with fresh autologous PBMC and $2.5 \mu \mathrm{g} / \mathrm{ml}$ concanavalin $\mathrm{A}$ as described above for the PBMC studies. Suppressor indices were then calculated as described.

In some experiments $10 \times 10^{6}$ lamina propria lymphocytes in $3 \mathrm{ml}$ culture medium were cultured with the same concentration of antigens as above. In addition, $10 \times 10^{6}$ lamina propria lymphocytes in $3 \mathrm{ml}$ were cultured alone. After seven days the cells were centrifuged using a Ficoll-paque gradient and washed three times in culture medium. The cell viability was assessed using the Trypan blue exclusion method, and the lamina propria lymphocytes were resuspended in culture medium to a concentration of $1 \times 10^{6}$ cells $/ \mathrm{ml}$. The lamina propria lymphocytes which had been cultured with antigen were then irradiated (2500 rad). Coculture experiments were then performed, using the unstimulated lamina propria lymphocytes as responder cells, and the suppressor index calculated as described above. The object of these experiments was to increase the viability of the lamina propria lymphocytes and to use autologous lamina propria lymphocytes in the responder phase of the assay (instead of PBMC).

ETHICS

Approval for the study was given by the Central Oxford Research and Ethics Committee.

\section{STATISTICS}

The data was analysed by the Mann-Witney U and Spearman correlation tests where appropriate. A value of $\mathrm{p}<0.05$ was taken as significant.

\section{Results}

PBMC

The antigens were used to induce the PBMC for seven days. This time was chosen on the basis of preliminary experiments which showed an adequate proliferative response at day 7 (Fig 1). The dose of antigen used was chosen on the basis of preliminary dose-response experiments (data not shown). After seven days the viability of the PBMC was assessed by the Trypan blue exclusion method. The viability was greater than $65 \%$ in all experiments, and greater than $80 \%$ in over $90 \%$ of the experiments.

Initial experiments were performed using antigen in both the inducer and responder phase. However, in order to obtain reasonable proliferation, the culture period in the responder phase needed to be at least seven days. This resulted in high background counts, making calculation of a suppressor index difficult, and also gave problems in cell viability since the total assay time was 14 days. Furthermore, using different antigens in the responder phase made comparisons difficult. Finally, a few patients showed little, if any, proliferative response to antigen so that there

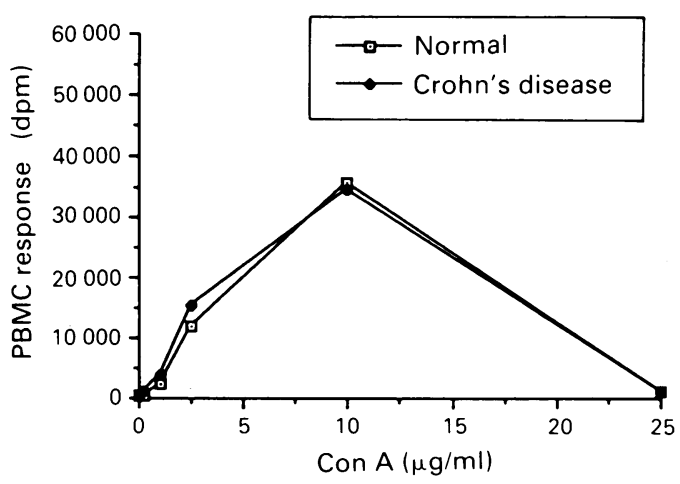

Figure 2: Proliferative response of peripheral blood mononuclear cells $(P B M C)(\mathrm{dpm})$ to varying doses of concanavalin A (Con A) after 64 hours. 
was no result from the responder cells making the calculation of a suppressor index impossible.

For these reasons a suboptimal dose of concanavalin A $(2.5 \mu \mathrm{g} / \mathrm{ml})$ was used (Fig 2). This gave a reproducible proliferative response after 64 hours in the fresh autologous PBMC used in the responder phase.

PBMC SUPPRESSOR ASSAYS (Table I)

Patients with ulcerative colitis had reduced suppression to Kunin antigen (median $\mathrm{SI}=-44 \cdot 3 \%$ ) compared with normal subjects $(+19 \cdot 4 \%)$. This was significant $(p<0.001)$. Compared with normal subjects, patients with ulcerative colitis also had significantly reduced suppression to $M$ avium ( $\mathrm{p}<0.01$ ), $M$ fortuitum, and $M$ nonchromogenecin $(\mathrm{p}<0.05)$. Patients with Crohn's disease had significantly reduced suppression to Johnin antigen compared with normal subjects and also to PPD, $M$ fortuitum, and Kunin antigens $(p<0.05)$. There was no correlation between the antigen stimulated proliferative responses in the primary cultures and the subsequent antigen induced suppression index (Table II).

\section{SKIN TESTS}

All the patients with inflammatory bowel disease and normal controls had a negative skin test using $0.1 \mathrm{ml} 20 \mu \mathrm{g} / \mathrm{ml}$ Johnin injected intradermally. Eight of 10 normal volunteers, 3 of 9 patients with Crohn's disease, and 2 of 7 patients with ulcerative colitis had a positive Mantoux test (Fig 3a). Subjects with a positive Mantoux test had a significantly higher PPD-induced suppressor index in PBMC compared with patients who were Mantoux negative $(\mathrm{p}<0.05$, Fig 3b).

\section{PBMC CELL DEPLETION STUDIES}

Satisfactory depletion was achieved in all but one experiment. The CD8 depleted populations were always $<5 \% \mathrm{CD} 8+$, and in two experiments $<2 \% \mathrm{CD} 8+$. After depletion of CD8 cells the suppressor index fell in 10 of 14 assays. In addition, after the depletion of CD8 cells the amount of soluble CD8 recovered from the

TABLE I Median (range) suppressor indices (\%) to the antigens in normal subjects, Crohn's disease and ulcerative colitis.

\begin{tabular}{llll}
\hline & $\begin{array}{l}\text { Normal } \\
\text { subjects }\end{array}$ & $\begin{array}{l}\text { Crohn's } \\
\text { disease }\end{array}$ & $\begin{array}{l}\text { Ulcerative } \\
\text { colitis }\end{array}$ \\
\hline Johnin & $+24 \cdot 4$ & $-27 \cdot 4^{\star}$ & $+16 \cdot 7$ \\
PPD & $(-21 \cdot 2$ to $+24 \cdot 1)$ & $(-130$ to $+37 \cdot 8)$ & $(-43 \cdot 0$ to $+31 \cdot 6)$ \\
Mycobacterium avium & $+12 \cdot 3$ & $-20 \cdot 3^{\star}$ & $+4 \cdot 8$ \\
$M$ kansasii & $(-50 \cdot 4$ to $+43 \cdot 5)$ & $(-149$ to $+13 \cdot 6)$ & $(-57 \cdot 7$ to $+25 \cdot 6)$ \\
M nonchr & $+7 \cdot 4$ & $-9 \cdot 3$ & $-37 \cdot 0 \star \star$ \\
M vaccin & $(-10 \cdot 1$ to $+45 \cdot 8)$ & $(-426$ to $+22 \cdot 4)$ & $(-51 \cdot 5$ to $+24 \cdot 6)$ \\
M fortuitum & $+4 \cdot 7$ & $-21 \cdot 6$ & $-6 \cdot 7$ \\
Kunin & $(-32 \cdot 2$ to $+45 \cdot 0)$ & $(-154$ to $+27 \cdot 9)$ & $(-71 \cdot 4$ to $+40 \cdot 9)$ \\
& $+19 \cdot 8$ & $-0 \cdot 5$ & $-3 \cdot 5 \star$ \\
& $(-38 \cdot 9$ to $+41 \cdot 2)$ & $(-317$ to $+36 \cdot 3)$ & $(-88 \cdot 8$ to $+42 \cdot 6)$ \\
& $+20 \cdot 5$ & $-8 \cdot 1$ & $-9 \cdot 5$ \\
\hline
\end{tabular}

Data analysed by Mann-Whitney $U$ test to analyse degree of reduced suppression in CD and UC: ${ }^{\star} p<0.05,{ }^{\star \star} p<0.01$ and ${ }^{\star \star \star} p<0.001$ culture supernatant fell to almost negligible amounts (Table III). The effects of depleting monocytes, CD2, and CD4 cells were not clear cut (data not shown).

\section{PBMC SOLUBLE CD8}

From the above results if seemed that antigen induced suppression requires $\mathrm{CD} 8+$ cells. Therefore, concentrations of soluble CD8 were measured in the supernatants of the antigen driven inducer phase, harvested at day 7 . Ninety six samples were analysed for soluble CD8, values ranging from 0 to $185 \mathrm{U} / \mathrm{ml}$. There was a direct, although weak, correlation between the soluble $C D 8$ value in the culture supernatant and the suppressor index $(r=0.25, p=<0.05$, Fig 4). This correlation was more pronounced in patients with inflammatory bowel disease, compared with controls.

This is further evidence that CD8 + cells are involved in the phenomenon of antigen induced suppression.

\section{LAMINA PROPRIA LYMPHOCYTES}

Lamina propria lymphocytes from six patients with ulcerative colitis, five patients with Crohn's disease, and six normal controls were assessed for suppressor cell function using autologous PBMC as responder cells. There was no significant difference in the suppressor indices for any
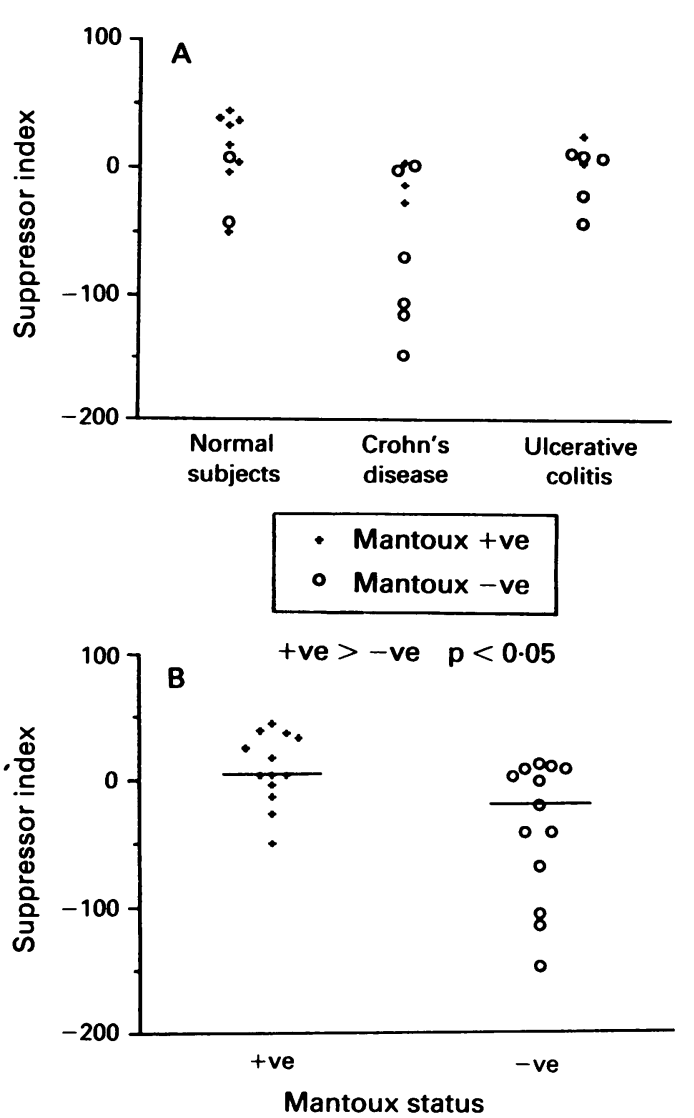

Figure 3: Tuberculin skin tests and purified protein derivative (PPD) induced suppression. (A) Mantoux status in normal subjects, Crohn's disease, and ulcerative colitis compared with their PPD induced suppressor index (\%). (B) Mantoux status in all subjects compared with their PPD induced suppressor index (\%). 
TABLE II Comparison of median proliferative responses $(P R)(\mathrm{dpm})$ of $5 \times 10^{6}$ peripheral blood mononuclear cells (PBMC) to optimal dose of antigen after seven days' culture and the subsequent suppressor index $(S I)(\%)$ in normal subjects.

\begin{tabular}{|c|c|c|c|c|c|c|}
\hline & \multicolumn{2}{|c|}{ Subject 1} & \multicolumn{2}{|c|}{ Subject 2} & \multicolumn{2}{|c|}{ Subject 3} \\
\hline & $P R$ & $S I$ & $P R$ & $S I$ & $P R$ & $S I$ \\
\hline PBMC alone & 1509 & - & 731 & - & 1260 & - \\
\hline Kunin & 6955 & $+27 \cdot 1$ & 28901 & $+15 \cdot 3$ & 10603 & +9.8 \\
\hline Johnin & 12891 & $+34 \cdot 5$ & 6756 & +16.0 & - & - \\
\hline PPD & 6435 & $+32 \cdot 0$ & 9637 & $-42 \cdot 1$ & 15037 & $+17 \cdot 7$ \\
\hline Mycobacterium avium & 7236 & $+45 \cdot 8$ & 1112 & $-3 \cdot 3$ & - & - \\
\hline M kansasii & 4298 & +26.8 & 1706 & $-26 \cdot 3$ & - & - \\
\hline M nonchr & 3813 & $+28 \cdot 1$ & 780 & $+4 \cdot 1$ & - & - \\
\hline$M$ vaccin & 3286 & $+32 \cdot 7$ & 1139 & $+15 \cdot 5$ & - & - \\
\hline$M$ fortuitum & 2853 & $+42 \cdot 4$ & 1079 & +13.9 & - & - \\
\hline
\end{tabular}

$\mathrm{p}=\mathrm{NS}$

TABLE III Suppressor indices (\%) induced by various antigens with undepleted peripheral blood mononuclear cells and a population of CD8 depleted peripheral blood mononuclear cells. The supernatant soluble $C D 8(\mathrm{U} / \mathrm{ml})$ is shown in parentheses.

\begin{tabular}{llll}
\hline Experiment no & Antigen & Undepleted & CD8 depleted \\
\hline 1 & Johnin & $+10 \cdot 5$ & $-1 \cdot 7$ \\
& PPD & $-17 \cdot 9$ & $-29 \cdot 4$ \\
& Kunin & $+2 \cdot 8$ & $+2 \cdot 7$ \\
2 & Mycobacterium fortuitum & $+10 \cdot 1$ & $-12 \cdot 0$ \\
& Johnin & $+33 \cdot 1$ & +11.9 \\
& PPD & $+20 \cdot 9$ & $-18 \cdot 8$ \\
& Kunin & $+5 \cdot 2$ & $+26 \cdot 3$ \\
3 & M fortuitum & $+16 \cdot 1$ & $+18 \cdot 5$ \\
& Johnin & $-10 \cdot 5$ & $-3 \cdot 8$ \\
4 & PPD & $+5 \cdot 4$ & $-12 \cdot 7$ \\
& Johnin & $+26 \cdot 3(44)$ & $-15 \cdot 4(14)$ \\
& PPD & $+33 \cdot 5(22)$ & $-9 \cdot 9(12)$ \\
& Kunin & $+44 \cdot 3(65)$ & $+6 \cdot 2(0)$ \\
& M fortuitum & $+29 \cdot 3(22)$ & $-66 \cdot 0(0)$ \\
\hline
\end{tabular}

TABLE IV Median (range) suppressor indices (\%) to the antigens in normal subjects, Crohn's disease, and ulcerative colitis with lamina propria lymphocytes (peripheral blood mononuclear cells).

\begin{tabular}{llll}
\hline & $\begin{array}{l}\text { Normal } \\
\text { subjects } \\
(n=6)\end{array}$ & $\begin{array}{l}\text { Crohn's } \\
\text { disease } \\
(n=5)\end{array}$ & $\begin{array}{l}\text { Ulcerative } \\
\text { colitis } \\
(n=6)\end{array}$ \\
\hline Johnin & $+26 \cdot 7$ & $+24 \cdot 3$ & $+37 \cdot 9$ \\
PPD & $(-5 \cdot 7$ to $+57 \cdot 3)$ & $(+18 \cdot 8$ to $+40 \cdot 7)$ & $\begin{array}{l}(+21 \cdot 9 \text { to }+65 \cdot 7) \\
+24 \cdot 8\end{array}$ \\
Mycobacterium avium & $(-17 \cdot 3$ & $+13 \cdot 3$ & $(-6 \cdot 8$ to $+82 \cdot 1)$ \\
M kansasii & $+18 \cdot 7$ to $+39 \cdot 0)$ & $(-7 \cdot 7$ to $+37 \cdot 1)$ & $+24 \cdot 6$ \\
M nonchr & $(-4 \cdot 3$ to $+38 \cdot 0)$ & $(-25 \cdot 2$ to $+14 \cdot 7)$ & $(+5 \cdot 5$ to $+45 \cdot 3)$ \\
M vaccin & $+13 \cdot 9$ & $-2 \cdot 9$ & $+26 \cdot 2$ \\
M fortuitum & $(-39 \cdot 9$ to $+63 \cdot 5)$ & $(-44 \cdot 6$ to $+40 \cdot 1)$ & $(-3 \cdot 8$ to $+39 \cdot 3)$ \\
Kunin & $+22 \cdot 5$ & $-10 \cdot 4$ & $+20 \cdot 4$ \\
& $(-19 \cdot 8$ to $+31 \cdot 8)$ & $(-31 \cdot 2$ to $+15 \cdot 3)$ & $(-2 \cdot 9$ to $+58 \cdot 6)$ \\
& $+17 \cdot 5$ & $+5 \cdot 0$ & $+28 \cdot 7$ \\
& $(-29 \cdot 1$ to $+35 \cdot 4)$ & $(-20 \cdot 8$ to $+32 \cdot 3)$ & $(-34 \cdot 6$ to $+82 \cdot 7)$ \\
& $+19 \cdot 4$ & $+13 \cdot 8$ & $+13 \cdot 2$ \\
& $(-10 \cdot 3$ to $+44 \cdot 8)$ & $(-47 \cdot 3$ to $+23 \cdot 5)$ & $(-30 \cdot 7$ to $+74 \cdot 4)$ \\
\hline
\end{tabular}

There is no significant difference in suppression between normal controls and patients with inflammatory bowel disease ( $p>0.05$ in all cases).

of the antigens used in any of these subgroups (Table IV). The lamina propria lymphocyte viability at day 7 , as assessed by Trypan blue viability exclusion was $62 \%$ (range $45 \%$ to $72 \%$ ). It was felt possible that the lack of difference in suppression between normal subjects and inflammatory bowel disease patients could reflect either poor cellular viability by the end of the experiment (day 9) or some intrinsic difference between the lamina propria lymphocytes (induced population) and PBMC (responder PBMC). For this reason further experiments were performed using lamina propria lymphocytes that had been centrifuged down a Ficoll-Paque gradient at the end of the
TABLE V Median suppressor indices(\%) of lamina propria lymphocytes, using autologous lamina propria lymphocytes as responder cells.

\begin{tabular}{lll}
\hline & $\begin{array}{l}\text { Normal } \\
\text { subjects } \\
(n=3)\end{array}$ & $\begin{array}{l}\text { Inflammatory bowel } \\
\text { disease } \\
(n=2)\end{array}$ \\
\hline Johnin & $-6 \cdot 2$ & $+16 \cdot 4$ \\
PPD & $(-17 \cdot 4$ to $+42 \cdot 1)$ & $(+11 \cdot 9$ to $+20 \cdot 9)$ \\
& $+4 \cdot 7$ & $-2 \cdot 0$ \\
Kunin & $(-1 \cdot 9$ to $+6 \cdot 7)$ & $(-19 \cdot 0$ to $+15 \cdot 1)$ \\
& $+11 \cdot 2$ & $-4 \cdot 2$ \\
& $(-13 \cdot 2$ to $+35 \cdot 6)$ & $(-44 \cdot 0$ to $+35 \cdot 6)$
\end{tabular}

inducer phase (day 7). The cell viability in these experiments was increased to $88 \%$ (range 82 to $98 \%$ ). Autologous (non-induced) lamina propria lymphocytes were used as responder cells in these experiments. There was still no difference in suppression between normal subjects and patients with inflammatory bowel disease (Table V).

\section{Discussion}

This study shows that there is reduced antigen induced suppressor activity in PBMC of patients with inflammatory bowel disease. Patients with inactive Crohn's disease have reduced suppressor cell activity to Johnin, PPD, $M$ fortuitum, and Kunin antigens. Patients with ulcerative colitis have reduced suppression to the Kunin, $M$ avium, $M$ nonchromogenecin, and $M$ fortuitum antigens. Subjects who have a positive Mantoux skin test have a significantly higher PPD induced suppressor cell activity in PBMC compared with Mantoux negative subjects.

The phenomenon of antigen induced suppression seems to be the result of a CD8 mediated mechanism, as depleting CD8+ cells reduces the effect and the level of soluble CD8 in the culture supernatant is directly related to the degree of suppression.

Mycobacteria share common epitopes ${ }^{24}$ and this may be one explanation for the reduced suppressor cell activity to a range of mycobacterial antigens observed in inflammatory bowel disease. However, since the same effect is seen in response to Kunin antigen, it is more likely that this phenomenon is a more generalised one.

One possible explanation for the generalised effect reported is that the assay employed is not truly antigen restricted, as low dose lectin was

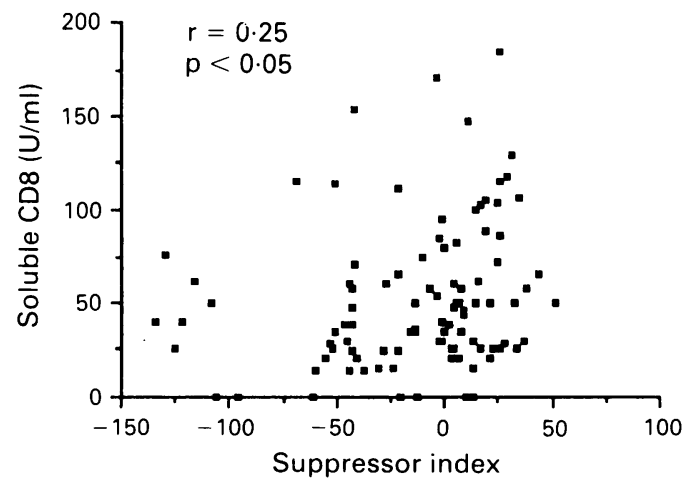

Figure 4: Supernatant soluble CD8, after 7 days' culture with antigen, compared with the suppressor index (\%). 
used in the responder phase. An alternative explanation is that the antigens used in the primary culture may have caused non-specific polyclonal activation of the lymphocytes under study. It is known that bacterial products, such as the antigens used in this study, are capable of polyclonal activation, although not usually of the same magnitude as lectins. ${ }^{25}$ This hypothesis may also provide an explanation for the quite high levels of stimulation seen after primary culture with antigen. However, these arguments do not explain the relation between the PPD induced suppressor index and the results of the Mantoux testing, which imply that the antigen induced suppressor cell assay used reflects, at least in part, cell mediated responses to specific antigen.

No correlation was observed between the proliferative responses to antigen in the primary culture and the subsequent SI to that antigen in normal subjects. It is known that there is no difference in the proliferative responses of PBMC from patients with inactive inflammatory bowel disease and normal subjects after stimulation with mycobacterial antigens. ${ }^{1626}$ It is therefore reasonable to hypothesise that the lack of antigen induced suppression observed in the PBMC of patients with inflammatory bowel disease does not simply reflect differences in the primary proliferative responses to the antigens between normal subjects and those with inflammatory bowel disease. Using a slightly different system, Ebert et al also observed no such correlation. ${ }^{16}$

These data disagree with those of Ebert et al, who found that the addition of $M$ paratuberculosis antigen to a concanavalin-A proliferation assay resulted in reduced proliferation of PBMC from patients with ulcerative colitis and Crohn's disease compared with control subjects. This was interpreted as showing increased antigen induced suppression. However, the assay system used is not well designed to investigate antigen induced suppression and therefore any discrepancy in the results may reflect differing immunological phenomena.

The present data are in keeping with most studies of non-specific suppression which have claimed a defect in suppressor cells in ulcerative colitis and Crohn's disease, although this defect in non-specific suppression is mainly seen in patients with active disease. Since we did not study patients with active disease, to avoid possible confounding effects of treatment or dietary deficiency, there are no data on how this might have affected antigen induced suppression.

The importance of the present data for the pathogenesis of mucosal disease remains speculative. However, it is possible that they may indicate a fundamental defect in the regulation of the immune response and may explain the heightened immune response to a wide variety of dietary, bacterial, and self-antigens seen in these diseases. Whether such a defect in immunoregulation is under genetic control and therefore predisposes an individual to develop a chronic inflammatory response after an acute insult or whether it is secondary to the chronic inflammation, remains to be established.
It is interesting to note that the most significant lack of suppression of PBMC in ulcerative colitis was to Kunin antigen, and in Crohn's disease to Johnin antigen. The bacteria from which these antigens are derived have created considerable interest in their role in the aetiopathogenesis of these diseases over the past few years. ${ }^{17182021}$

If reduced antigen induced suppression in PBMC in inflammatory bowel disease is important for pathogenesis, we would have expected to be able to reproduce the results at mucosal level. However, differences in antigen induced suppression between normal subjects and patients with inflammatory bowel disease in the lamina propria lymphocyte population could not be shown. Increasing the cell viability and using an autologous lamina propria lymphocyte responder system (instead of PBMC) made no difference to this finding. There are several possible explanations for this. Firstly, in the lamina propria lymphocyte studies (unlike in the PBMC studies) the most subjects with inflammatory bowel disease were taking corticosteroid medication. It is known that corticosteroids affect suppressor cell activity in vitro. ${ }^{27}{ }^{28}$ Secondly, the chemicals and enzymes used in the procedure to isolate the lamina propria lymphocytes could possibly have affected their function. A third explanation for this is that the lamina propria lymphocytes consist of a different subpopulation of cells, compared with PBMC. It is known that CD4/CD8 ratio is similar in lamina propria lymphocytes and PBMC in normal and control subjects. ${ }^{29}{ }^{30}$ However, compared with PBMC, there is an increased proportion of CD45Ro $T$ cells ('memory'/helper-inducer $T$ cells) in the lamina propria, particularly in areas of inflammation. ${ }^{31-34}$ It would, therefore, be reasonable to postulate that the 'resting tone' of the lamina propria lymphocytes is help rather than suppression, as originally suggested by Elson in $1985 .{ }^{15}$ If this is the case, it could explain the lack of difference in suppressor cell activity between normal subjects and patients with inflammatory bowel disease.

The authors thank Mr N J McC Mortensen and Mr M G W Kettlewell for kindly providing the colonic resection specimens. This work was supported by Sandoz Pharmaceuticals.

1 Hodgson HJF, Wands JR, Isselbacher KJ. Decreased suppressor cell activity in inflammatory bowel disease. Clin Exp Immunol 1978; 32: 451-8.

2 Victorino RMM, Hodgson HJF. Spontaneous suppressor cell function in inflammatory bowel disease. Dig Dis Sci 1981; 26: $801-6$.

3 Knapp W, Smolen JS, Lanzer G, Berger R, Menzel EJ, Grabner $G$, et al. Con A induced suppressor cell activity in IBD and other inflammatory diseases. In: Pena AS, IBD and Other inflamma AS, Weterman IT, Booth CC, Strobar W, eds. Recent advances in 1981: 380-9.

4 Auer IO, Roder A, Fröhlich J. Immune status in Crohn's disease. VI Immunoregulation evaluated by multiple, distinct $\mathrm{T}$-suppressor cell assays of lymphocyte proliferation, and by enumeration of immunoregulatory $\mathrm{T}$-lymphocyte subsets. Gastroenterology 1984; 86: 1531-43.

5 Doldi K, Manger B, Koch B, Riemann J, Hermanek P, Kalden JR. Spontaneous suppressor cell activity in the peripheral blood of patients with malignant and chronic inflammatory bowel diseases. Clin Exp Immunol 1984; 55: 655-63.

6 Kelleher D, Murphy A, Whelan CA, Feighery C, Weir DG, Keeling PWN. Defective suppression in the autologous mixed lymphocyte reaction in patients with Crohn's disease. Gut 1989; 30: 839-44.

7 Ginsburg $\mathrm{CH}$, Falchuk ZM. Defective autologous mixedlymphocyte reaction and suppressor cell generation in 
patients with inflammatory bowel disease. Gastroenterology 1982; 83: 1-9.

8 Holdstock G, Chastenay BF, Krawitt EL. Functional suppressor $T$ cell activity in Crohn's disease and the effects of sulphasalazine. Clin Exp Immunol 1982; 48: 619-24.

9 Elson CO, Graeff AS, James SP, Strober W. Covert suppressor $\mathrm{T}$ cells in Crohn's disease. Gastroenterology 1981; 80: 1513-21

10 Davidsen B, Kristensen E. Lymphocyte subpopulations, ymphoblast transformation activity and Con A induced suppressor activity in patients with ulcerative colitis and Crohn's disease. Scand f Gastroenterol 1987; 22: 785-90.

11 Shorter RG. Tg cells in non-specific concanavalin A-induced suppressor activity in vitro in colonic inflammatory bowel disease and in colorectal carcinoma. In: Pena AS, Weterman IT, Booth CC, Strobar W, eds. Recent advances in Crohn's IT, Booth CC, Strobar W, eds. Recent advances in

12 Fiocchi C, Battisto JR, Farmer RG. Gut mucosal lymphocytes in inflammatory bowel disease. Isolation and preliminary functional characterisation. Dig Dis Sci 1979; 24: 705-17.

13 Goodacre RL, Bienenstock J. Reduced suppressor cell activity in intestinal lymphocytes from patients with Crohn's disease. Gastroenterology 1982; 82: 653-8.

14 Fiocchi C, Youngman KR, Farmer RG. Immunoregulatory function of human intestinal mucosal lymphoid cells: evidence for enhanced suppressor cell activity in inflammatory bowel disease. Gut 1983; 24: 692-701.

15 Elson CO, Machelski E, Weiserbs DB. T cell-B cell regulation in the intestinal lamina propria in Crohn's regulation in the intestinal lamina prop
disease. Gastroenterology 1985; 89: 321-7.

16 Ebert EC, Bhatt BD, Liu S, Das KM. Induction of suppressor cells by Mycobacterium paratuberculosis antigen in inflamcells by Mycobacterium paratuberculosis antigen in inflam-

17 Hampson SJ, McFadden JJ, Hermon-Taylor J. Mycobacteria and Crohn's disese. Gut 1988; 29: 1017-9.

18 Blaauwgeers HJLG, Mulder CJJ, Das PK, Haagsma J, Tytgat GNJ. Crohn's disease, a mycobacterial aetiology? Eur $\mathcal{f}$ Gastroenterol 1990; 2: 237-40.

19 Stanford JL, Dourmashkin R, Mcintyre G, Visuvanathan S Do mycobacteria exist in alternative physical forms and what part do they play in the aetiology in inflammatory bowel disease. In: MacDermott RP, ed. Inflammatory bowe disease. Current status and future approach. Amsterdam: Elsevier Science, 1988; 503-8.

20 Lagercrantz R, Hammarstrom S, Perlmann P, Gustafsson BE. Immunological studies in ulcerative colitis IV origin of Immunological studies in ulcerative colitis IV

21 Mee AS, McLaughlin JE, Hodgson HJF, Jewell DP. Chronic immune colitis in rabbits. Gut 1979; 20: 1-5.
22 Mahida YR, Wu KC, Jewell DP. Respiratory burst activity of Mahida YR, Wu KC, Jewell DP. Respiratory burst activity of disease. Gut 1989; 30: 1362-70.

23 Bull DM, Bookman MA. Isolation and functional characterisation of human intestinal mucosal lymphoic cells. $\mathcal{f}$ Clin Invest 1977; 59: 966-74.

24 Stanford JL. Immunologically important constituents of mycobacteria: antigens. In: Routledge $\mathrm{C}$, Stanford JL, eds. The biology of the mycobacteria 2. London: Academic Press, 1983: 85-127.

25 Vordermeier M, Stab K, Bessler WG. A defined fragment of bacterial protein I $(\mathrm{OmpF})$ is a polyclonal B-cell activator. Infect Immunol 1986; 51: 233-9.

26 Ibbotson JP, Lowes JR, Chahal $\mathrm{H}$, Gaston $\mathrm{H}$, Kumararante DS, Alexander-Williams J. Pathogenesis of inflammatory DS, Al disease: mucosal all mediated immunity to mycoDes Al166.

27 Haynes BF, Fauci AS. Mechanisms of corticosteroid action on lymphocyte subpopulations. IV Effects of in vitro hydrocortisone on naturally occurring and mitogen-induced suppressor cells in man. Cell Immunol 1979; 44: 157-68.

28 Smith CI, Sveigaard A. Concanavalin A-induced suppresso ymphocytes in normal individuals. Scand $\mathcal{F}$ Immunol 1981 13: 483-92.

29 Selby WS, Jewell DP. T lymphocyte subsets in inflammatory bowel disease: peripheral blood. Gut 1983; 24: 99-105.

30 Selby WS, Jannossy G, Bofill M, Jewell DP. Intestinal lymphocyte subpopulations in inflammatory bowel disease: an analysis by immunohistological and cell isolation techniques. Gut 1984; 25: 32-40.

31 Moore $\mathrm{K}$, Walters MT, Jones DB, Garvey E, Harvey J Cawley MID, et al. An immunological study of CD4+ lymphocyte subsets within inflammatory lesions with special lymphocyte subsets within inflammatory lesions with special reference to rheumatoid arthritis and

32 James SP, Fiocchi C, Graeff AS, Strober W. Phenotypic nalysis of lamina propria lymphocytes. Predominance of helper-inducer and cytolytic T-cell phenotypes and deficiency of suppressor inducer phenotypes in Crohn's disease. Gastroenterology 1986; 91: 1483-9.

33 Senju M, Wu KC, Mahida YR, Jewell DP. Two-colour immunofluorescence and flow cytometric analysis of lamina propria lymphocyte subsets in ulcerative colitis and Crohn's disease. Dig Dis Sci 1991; 36: 1453-8.

34 Kanof ME Strober W, Fiocchi C, Zeitz M, James SP. CD4 positive Leu 8 negative helper-inducer cells predominate in positive Leu 8 negative helper-inducer cells predominate in 3029-36.

\section{更}

\section{.}

응 